\title{
Analisis Strategi Pengembangan Objek Wisata Danau Bandar Kayangan di Kota Pekanbaru
}

\author{
AFISI SABRI \\ Akademi Pariwisata Engku Puteri Hamidah Pekanbaru, Riau \\ email: afisi.sabri@yahoo.com
}

\begin{abstract}
Riau Province to develop tourism-development of the area to attract investors and provide easiness for them through regulations issued by the local government. Thus expected tourism in Riau Province can develop properly. One is the airport Heaven attractions Lembah Sari which is one of the sights of natural shades Pekanbaru. This type of research using descriptive technique is sample visitors 50 people taken by accidental, collecting data using questionnaires and descriptive data analysis. Based on the survey results revealed that the interest of society towards the development of attraction Banda Kayangan lake is quite good. Then the strategy of the Department of Tourism in developing attractions Kayangan Lake City to become a tourist attraction that can be reliable in Pekanbaru do several things: 1) Divide the airport Kayangan Lake area into several zones; 2) Make referrals development masterplan. There are several obstacles that are owned by the Department of Tourism in developing attractions Kayangan Lake City. It was of course very inhibits against the planned development. Existing barriers are: inadequate management, absence of interested investors to invest, existence of some corrupt officials to fund the development and the lack of oversight of contractors.
\end{abstract}

Keywords: Interest of Society and Development Strategy Attractions

Propinsi Riau melakukan pengembanganpengembangan kawasan pariwisata dengan menarik minat investor dan memberikan kemudahan-kemudahan bagi mereka melalui peraturan-peraturan yang dikeluarkan oleh pemerintah setempat. Diharapkan dengan demikian kepariwisataan di Propinsi Riau dapat berkembang dengan baik.

Pekanbaru merupakan Ibukota propinsi yang memiliki penduduk yang cukup ramai dengan berbagai aktifitas bisnis. Sebagai Ibukota dari Propinsi Riau, Kota Pekanbaru cukup ramai dikunjungi oleh orang-orang yang melakukan kegiatan bisnis dan lain sebagainya. Para pendatang yang singgah ke Kota Pekanbaru pada umumnya adalah melakukan transit yang kemudian melanjutkan perjalanan ke kota lainnya baik itu daerah-daerah yang ada di Propinsi Riau maupun ke daerah kota tetangga dari Propinsi Riau.

Perkembangan pariwisata dewasa ini sangat pesat dan memberikan peluang terhadap pertumbuhan ekonomi nasional maupun regional. Untuk itu pembangunan pariwisata terus dipacu dan pemerintah mempunyai keyakinan bahwa pariwisata dapat menjadi sektor andalan menggantikan minyak dan gas bumi yang selama ini menjadi tumpuan pemerintah dalam menunjang penerimaan negara. Dalam rangka menghadapi tantangan dan kemajuan zaman serta meningkatkan kesejahteraan rakyat, Negara Republik Indonesia terus giat melaksanakan pembangunan di berbagai bidang. Berhasil tidaknya pembangunan tersebut akan sangat tergantung pada partisipasi disertai tekad dan semangat dari seluruh rakyat Indonesia. Disamping itu harus pula ditopang dengan disiplin dan tanggung jawab dari seluruh aparat pemerintah baik di tingkat pusat maupun daerah. Pembangunan sebagai upaya sadar manusia dengan tujuan mencapai kemajuan peningkatan kesejahteraan hidupnya, selalu diupayakan dari masa ke masa.

Kodya Pekanbaru memiliki potensi wisata yang cukup besar, namun potensi yang telah tersedia itu harus didukung dengan pengadaan dan kesiapan sarana serta prasarana yang memadai. Salah satu potensi pariwisata yang dimiliki oleh Kota Pekanbaru adalah Bandar Kayangan Lembah Sari atau yang lebih dikenal dengan Danau Buatan di Lembah Sari 
Rumbai. Minimnya tempat wisata alam dan bermain di Kota Pekanbaru membuat beberapa tempat bermain yang berada di malmal dan juga hotel-hotel yang menyediakan water park menjadi incaran warga Pekanbaru dan juga dari kabupaten/kota di Riau. Namun tahun 2012 dan dua tahun ke depan Danau Bandar Khayangan Lembah Sari akan menjadi tempat incaran masyarakat untuk menghabiskan waktu liburan.

Wisata Bandar Kayangan Lembah Sari merupakan salah satu tempat wisata Pekanbaru yang bernuansa alami. Objek wisata yang satu ini berlokasi di Kecamatan Rumbai Pekanbaru, Bandar Kayangan Lembah Sari semula berbentuk bendungan irigasi yang kini dipoles menjadi salah satu objek wisata masyarakat Pekanbaru, Riau memang masih bernuansa alami. Pemandangan alam sekitar Danau Bandar Kayangan Lembah Sari ini memiliki panorama yang indah, sejuk, nyaman dan bukit-bukit yang ditumbuhi pepohonan, memungkinkan dikembangkan sebagai tempat atraksi wisata tirta seperti berenang, memancing, bersepeda air dan lain-lain.

Dalam rangka meningkatkan potensi wisata khususnya wisata danau Bandar Kayangan Lembah Sari, berbagai cara dilakukan oleh Pemerintahan Kota Pekanbaru melalui Dinas Pariwisata seni Dan Budaya, dari mulai memperbaiki infrastruktur, pengelolaan, hingga mengganti nama Danau Buatan menjadi Bandar Kayangan Lembah Sari yang peresmian nama dilakukan pada tanggal 16 April 2011. Hal ini dilakukan Dinas Pariwisata seni Dan Budaya Kota Pekanbaru untuk menarik wisatawan baik lokal maupun wisatawan dari daerah luar

Danau Bandar Kayangan harus diwujudkan menjadi lokasi wisata utama di Kota Pekanbaru. Karena itu, semua sarana dan prasarana untuk Danau Bandar Kayangan harus dibangun sehingga Danau Bandar Kayangan menjadi obyek wisata ternama di Kota Bertuah. Pengelolaan Danau Bandar Kayangan Lembah Sari ini belum maksimal dikarenakan terlalu jauh dari kota, selain itu dalam hal penunjang lainnya, seperti arena bermain, transportasi terus saja menjadi kendala hingga saat sekarang ini. Karenanya objek Riau ini sedang direnovasi dan menghabiskan biaya yang tidak sedikit guna diubah menjadi lokasi tujuan Wisata andalan Riau. Danau Bandar Kayangan Lembah Sari jika dikelola dengan serius maka akan menjadi andalan sebagai objek wisata se- Sumatera, tapi memang membutuhkan dana yang besar. Saat ini banyak investor tertarik ingin menanamkan modal mereka di danau ini. Jika sarana pendukung seperti infrastruktur dibenahi, 34 tahun ke depan danau ini mungkin akan mendapat wisatawan ramai tiap harinya. diperlukan suatu program yang berkesinambungan dan kerja sama yang baik antar satker terkait seperti Dinas Kebudayaan dan Pariwisata, Dinas Perhubungan Komunikasi Informatika dan Dinas Pekerjaan Umum untuk mengembangkan Danau Bandar Kayangan. Jika semuanya sudah saling terpadu, tidak mustahil Danau Bandar Kayangan akan menjadi obyek wisata yang benar-benar mampu dihandalkan.

Dinas Pariwisata Seni Dan Budaya Kota Pekanbaru sedang merancang pembuatan, water boom, tempat parkir, taman Wisata Pendidikan, Hutan Alam wisata, taman pancing kemudian permainan air. Untuk Pembangunan water boom Pemko akan memanfaatkan lahan seluas dua hektar. Begitu untuk kawasan wisata pendidikan lahan parkir juga disediakan cukup luas. Selain itu, Dinas Pariwisata Seni Dan Budaya Kota Pekanbaru juga sedang melakukan peningkatan jalan pada tahun 2012 ini diyakini sudah selesai. Tahap pertama satu jalur dengan panjang seluas 1,5 kilometer di lokasi Danau Bandar Kayangan Lembah Sari tersebut. Agar itu terealisasi segera maka Pemko Pekanbaru melalui Dinas Pariwisata Seni Dan Budaya terus berusaha mendapatkan sharing anggaran dari pemerintah pusat melalui APBN. Dinas Pariwisata Seni Dan Budaya Pekanbaru optimis tahun 2012 ini Danau Bandar Khayangan Lembah Sari menjadi tujuan masyarakat Riau dan juga wisatawan dari luar daerah. Terutama para official dan 
atlet yang bertanding pada PON ke-XVIII. Pemerintah juga berjanji bakal mengadakan berbagai event penting di Danau Bandar Kayangan yang memiliki luas wilayah 14 hektare tersebut.

Dilihat dari besaran anggaran untuk pengelolaan Danau Bandar Kayangan Lembah Sari oleh perusahaan Dinas Pariwisata Seni Dan Budaya Pekanbaru membutuhkan dana sekitar Rp10 miliar tiap tahunnya. Itulah sebabnya diharapkan Pemprov Riau bisa membantu melalui APBD nya. Sekarang Danau Bandar Kayangan Lembah Sari masih dikelola Dinas Pariwisata Seni Dan Budaya Pekanbaru namun belum cukup mampu mengelola kawasan wisata tersebut. Untuk mengembangkan dan mengelola Danau Bandar Kayangan Lembah Sari agar menjadi terkenal seperti Ancolnya Jakarta tentu tak bisa mengandalkan alam saja, akan tetapi harus dilengkapi berbagai fasilitas yang benar-benar diperlukan masyarakat. Terutama lokasi bermain, bersantai dan tempat istirahat bagi wisata dari luar kota yang terpenting untuk transportasi dan segala bentuk arena permainan yang modren saat ini.

Upaya Dinas Pariwisata Seni Dan Budaya Pekanbaru mengembangkan kawasan wisata Danau Bandar Kayangan Lembah Sari hingga kini belum kunjung direalisasi. Cara yang dilakukan, mulai dari dikelola sendiri sampai mencari pihak ketiga yang hingga saat ini keinginan mengembangkan Bandar Kayangan Lembah Sari masih belum menunjukkan ada perkembangan yang signifikan. Tidak itu saja, walaupun ada sejumlah investor datang ke Dinas Pariwisata Seni Dan Budaya Pekanbaru mengaku berminat mengembangkan kawasan itu, ternyata, Bandar Kayangan Lembah Sari tak juga ditata lebih menarik. Terkendalanya pengembangan pembangunan Danau Bandar Kayangan Lembah Sari ini oleh Dinas Pariwisata Seni dan Budaya Kota Pekanbaru, dikarenakan adanya pemotongan Dana Bagi Hasil (DBH) antara Dinas Pariwisata dengan Perusahaan Daerah (PD) sehingga berimbas terhadap pembangunan Objek Wisata
Unggulan Danau Bandar Kayangan yang tidak bisa dilanjutkan.

Seperti yang diketahui, kondisi wisatawan kawasan wisata alam Bandar Kayangan Lembah Sari selama ini relatif kecil. Padahal, dengan lahan cukup luas sangat berpotensi kawasan itu menjadi kawasan wisata representatif di daerah ini. Melihat hal demikian maka sangat dibutuhkan strategi yang bagus dari Dinas Pariwisata Seni Dan Budaya dalam mengelola serta mengembangkan Danau Bandar Kayangan Lembah Sari sehingga dapat menjadi wisata yang diandalkan di Pekanbaru.

Dalam bidang manajemen, definisi mengenai strategi cukup beragam dan bervariasi dari beberapa ahli dan pengarangnya. Gerry Johnson dan Kevan Scholes (2010: 22) mendefinisikan strategi sebagai arah dan cakupan jangka panjang organisasi untuk mendapatkan keunggulan melalui konfigurasi sumber daya alam dan lingkungan yang berubah untuk mencapai kebutuhan pasar dan memenuhi harapan pihak yang berkepentingan (stakeholder).

Menurut Pearce dan Robinson (1997:20) Strategi adalah 'rencana main' suatu perusahaan. Strategi mencerminkan kesadaran perusahaan mengenai bagaimana, kapan dan di mana ia harus bersaing menghadapi lawan dan dengan maksud dan tujuan untuk apa. Sedangkan menurut Lynch seperti yang dikutip oleh Wibisono (2006: 50-51), strategi perusahaan merupakan pola atau rencana yang mengintegrasikan tujuan utama atau kebijakan perusahaan dengan rangkaian tindakan dalam sebuah pernyataan yang saling mengikat. Strategi perusahaan biasanya berkaitan dengan prinsip-prinsip secara umum untuk mencapai misi yang dicanangkan perusahaan, serta bagaimana perusahaan memilih jalur yang spesifik untuk mencapai misi tersebut.

Menurut Anthony dan Govindarajan (1995: 12) juga menambahkan bahwa perencanaan strategik merupakan suatu proses manajemen yang sistematis yang didefinisikan sebagai proses pengambilan 
keputusan atas program-program yang akan dilaksanakan oleh organisasi dan perkiraan sumber daya yang akan dialokasikan dalam setiap program selama beberapa tahun mendatang. Sedangkan menurut Morrisey (1995:45), strategi adalah proses untuk menentukan arah yang harus dituju oleh perusahaan agar misinya tercapai dan sebagai daya dorong yang akan membantu perusahaan dalam menentukan produk, jasa, dan pasarnya di masa depan. Dalam menjalankan aktifitas operasional setiap hari di perusahaan, para pemimpin dan manajer puncak selalu merasa bingung dalam memilih dan menentukan strategi yang tepat karena keadaan yang terus menerus berubah.

$$
\text { Igor Ansoff (1990: 15), }
$$

mendefinisikan strategi sebagai proses manajemen, hubungan antara perusahaan dengan lingkungan, terdiri dari perencanaan strategik, perencanaan kapabilitas, dan manajemen perubahan. Sedangkan Arnoldo C. Hax dan Nicholas S. Manjluk (1991: 32), mendefinisikan strategi sebagai cara menuntun perusahaan pada sasaran utama pengembangan nilai korporasi, kapabilitas manajerial, tanggungjawab organisasi, dan sistem administrasi yang menghubungkan pengambilan keputusan strategik dan operasional pada seluruh tingkat hirarki, dan melewati seluruh lini bisnis dan fungsi otoritas perusahaan. John A. Pearce II dan Richard B. Robinson Jr., (2003: 21), Mendefinisikan strategi sebagai seperangkat keputusan dan tindakan yang menghasilkan formulasi dan implementasi dari rencana yang didesain untuk mencapai tujuan. Sedangkan Fred R. David (2005: 33) mendefinisikan strategi sebagai cara untuk mencapai tujuan jangka panjang. Strategi bisnis bisa berupa perluasan geografis, diversifikasi, akusisi, pengembangan produk, penetrasi pasar, rasionalisasi karyawan, divestasi, likuidasi dan joint venture. Sedangkan manajemen strategis dapat didefinisikan sebagai seni dan pengetahuan dalam merumuskan, mengimplementasikan, serta mengevaluasi keputusan-keputusan lintas fungsional yang memungkinkan suatu organisasi untuk mencapai tujuannya.
WF Glueck dan LR Jauch (2009: 41) mendefinisikan strategi sebagai rencana yang disatukan, luas dan berintegrasi yang menghubungkan keunggulan strategis perusahaan dengan tantangan lingkungan, yang dirancang untuk memastikan bahwa tujuan utama dari perusahaan dapat dicapai melalui pelaksanaan yang tepat oleh organisasi.

Dari berbagai pengertian dan definisi mengenai strategi, secara umum dapat didefinisikan bahwa strategi itu adalah rencana tentang serangkaian manuver, yang mencakup seluruh elemen yang kasat mata maupun yang tak-kasat mata, untuk menjamin keberhasilan mencapai tujuan.

Selanjutnya berbicara mengenai objek wisata tidak terlepas dari makna wisatawan menurut Oka A. Yoeti (1999 : 34) mengatakan bahwa wisatawan adalah seseorang yang melakukan perjalanan untuk sementara waktu tidak kurang selama 24 jam dan ia semata-semata sebagai konsumen bukan mencari nafkah atau bekerja tetap di tempat yang ia kunjungi. Menurut Happy Marpaung (2002 : 23) mengatakan bahwa PBB telah menetapkan batasan tourist (wisatawan) adalah para wisatawan sementara yang tinggal sekurang-kurangnya 24 jam di negara yang dikunjungi dan tujuan perjalanan dapat diklasifikasikan dari beberapa golongan yaitu, untuk bersenang-senang (rekreasi, berlibur, kesehatan, belajar, keagamaan dan olah raga), bisnis, keluarga, mission, rapat. Sementara itu excursionist adalah orang yang merupakan wisatawan sementara yang kurang dari 24 jam di negara atau daerah yang dikunjunginya termasuk para pelaku perjalanan melalui kapal-kapal pesiar.

Objek wisata atau dengan istilah "tourist attraction" yaitu segala sesuatu yang menjadi daya tarik bagi orang untuk mengunjungi suatu daerah tertentu. Hal-hal yang dapat menarik orang untuk berkunjung ke suatu tempat daerah tujuan wisata, menurut Tontje Tnunay (2008: 32) diantaranya ialah : 1). Benda-benda yang tersedia dan terdapat di alam semesta, yang 
dalam istilah Natural Amenities. Yang termasuk dalam kelompok ini adalah lklim, misalnya cuaca cerah banyak cahaya matahari, sejuk, panas, hujan, dan sebagainya. Fauna dan flora seperti tanaman-tanaman yang aneh (uncommon vegetation), burungburung, ikan, binatang buas (wild life), taman nasional (national park), daerah perburuan dan sebagainya. Pusat-pusat kesehatan (health center), sumber air mineral (natural spring of mineral water), sumber air panas (hot spring). 2). Hasil ciptaan manusia yaitu benda-benda yang bersejarah, kebudayaan dan keagamaan, misalnya: Monumen bersejarah, dan sisa peradaban masa lampau. Museum, art gallery, perpustakaan, kesenian rakyat, handycraft. Acara tradisional, pameran, festival, upacara perkawinan dan lain-lain. Rumah-rumah ibadah, seperti mesjid, gereja, kuil atau candi maupun pura. 3). Tata Cara Hidup Masyarakat (The way of life) yaitu Tata cara hidup tradisional dari suatu masyarakat merupakan salah satu sumber yang amat panting untuk ditawarkan kepada para masyarakat. Hal semacam ini sudah terbukti, betapa besar pengaruhnya dalam bidang ekonomi sehingga dapat dijadikan event yang dijual.

Menurut Prof. Mariotti (Yoeti, 2007 : 164) ketiga hal tersebut diatas yang dapat menarik wisatawan untuk berkunjung ke suatu daerah. Suatu daerah tujuan wisata mempunyai banyak hal yang dapat ditawarkan dalam pengembangan suatu daerah untuk menjadi suatu daerah tujuan wisata, agar ia dapat menarik untuk dikunjungi oleh wisatawan potensial, harus memenuhi tiga syarat, yaitu: Daerah itu harus mempunyai apa yang disebut dengan Something to see. Maksudnya, daerah tersebut harus mempunyai daya tarik khusus, disamping itu juga harus mempunyai atraksi wisata yang dapat dijadikan sebagai "entertainments" bila orang datang ke sana. Selanjutnya daerah tersebut harus mempunyai " something to do ". Selain banyak yang dapat dilihat dan disaksikan, harus pula disediakan fasilitas rekreasi atau amusements yang dapat membuat mereka betah tinggal lebih lama. Kemudian yang harus ada ialah " something to buy ". Di tempat tersebut harus tersedia fasilitas untuk berbelanja (shopping) terutama barang-barang souvenir dan kerajinan rakyat sebagai oleh-oleh untuk dibawa pulang ke tempat asal masingmasing. Selain itu fasilitas lain yang harus tersedia adalah Money Changer, Bank, Kantor Pos, Telepon dan lain-lain.

Kita hanya akan menyebut sesuatu itu sebagai obyek wisata, bila untuk melihat obyek itu tidak ada kesiapan dilakukan terlebih dahulu, tanpa bantuan orang lain misalnya : pemandangan, gunung, danau, lembah dan lain-lain. Atraksi wisata ialah sesuatu yang dipersiapkan terlebih dahulu agar dapat dilihat, dinikmati, dan yang termasuk dalam hal ini : Tari-tarian, Nyanyian, Kesenian rakyat tradisonal, Upacara adat dan lain-lain.

Dalam kegiatan pariwisata, atraksiatraksi ini harus dikoordinasikan dalam suatu paduan penyajian atraksi yang harmonis, menarik dan mengagumkan. Selanjutnya berbagai ragam atraksi disajikan secara terpadu dan latar belakang panorama keindahan alam, peninggalan kebudayaan purbakala yang megah serta seni tari dipentaskan secara harmonis dalam suatu paket penyajian yang ditangani secara baik dan mengindahkan kaidah-kaidah lingkungan masyarakat setempat sebagai upaya pelestarian tata cara hidup yang harus dihormati.

Dewasa ini, pemaduan atraksiatraksi wisata dalam satu paket penyajian harus diidentifikasikan dan diatur secara baik misalnya upacara adat, festival, pekan raya, pesta olah raga, sendratari dan sebagainya.

Suatu atraksi wisata dikatakan berhasil bila memiliki persyaratan (Soekadijo 2006 : 61) sebagai berikut : Kegiatan (act) dan obyek (artifact) yang merupakan atraksi itu sendiri harus dalam keadaan yang baik. Karena atraksi wisata itu harus disajikan dihadapan wisatawan maka cara penyajiannya (presentasinya) harus tepat. Atraksi wisata adalah terminal dari suatu mobilitas spesial suatu perjalanan. Oleh karena itu juga harus 
memenuhi semua determinan mobilitas spesial, yaitu akomodasi, transportasi, dan promosi serta pemasaran. Keadaan di tempat atraksi harus dapat menahan wisatawan cukup lama. Kesan yang diperoleh wisatawan waktu menyaksikan atraksi wisata harus diusahakan supaya bertahan selama mungkin.

Pengembangan suatu objek wisata menurut penulis merupakan suatu hal yang besar karena melingkupi banyak pihak, biaya, pemikiran dan partisipasi dari warga setempat, pemerintah setempat dan investor yang berminat. Pengembangan daya tarik wisata sendiri memiliki tujuan untuk berkembang kearah yang lebih baik yang akhirnya dapat menghasilkan manfaat yang dapat dirasakan oleh banyak orang di samping untuk pemeliharaan obyek wisata itu sendiri.

Kaelany H. D, dalam bukunya Peluang di Bidang Pariwisata (2007: 20) yang menyebutkan Potensi merupakan kelebihan dan daya tarik wisata yang dimiliki suatu obyek wisata. Ada berbagai jenis objek wisata yang menjadi daya tarik wisatawan dan di sini, penulis mendasari konsep tulisan Oka A Yoeti, dalam bukunya Pengantar Ilmu Pariwisata, (2005:13) yang menjelaskan berbagai jenis objek wisata, diantaranya: Obyek Wisata Alam, Obyek wisata alam adalah obyek wisata yang daya tariknya bersumber pada tindakan sumber daya alam dan tata lingkungannya. Obyek Wisata Budaya, Obyek wisata budaya adalah obyek wisata yang daya tariknya bersumber pada kebudayaan dan keunikan adat istiadat tiap daerah, contohnya tari-tarian, ukir-ukiran, upacara adat, dan lain-lain. Obyek Wisata Buatan Manusia, Obyek wisata buatan manusia adalah obyek wisata yang daya tariknya bersumber pada buatan manusia, contohnya museum, candi, dunia fantasi, disneyland, dan lain-lain.

Sebagai objek wisata yang daya tariknya bersumber pada keindahan alam, pantai dengan sendirinya tergolong jenis objek wisata alam karena memiliki daya tarik alam dapat dikembangkan dengan menonjolkan keindahan pantai dan air lautnya yang bersih. Jenis objek wisata yang kedua adalah objek wisata budaya yang daya tarik utamanya bersumber pada kebudayaan dan keunikan adat istiadat suatu daerah. Konsep pengembangan daya tarik wisata dalam buku karya Fandeli, (2005 :152-153) yang isinya mengenai Pengembangan daya tarik wisata. Pada hakekatnya, pembangunan obyek dan daya tarik wisata adalah: Pembangunan sosial ekonomi Regional, Kebutuhan rekreasi masyarakat, Memperoleh keuntungan dan Optimalisasi sumber daya yang mempunyai fungsi lain.

Dari konsep penulisan diatas, dapat dilihat bahwa pembangunan daya tarik wisata juga mengarah pada perbaikan ekonomi regional, peningkatan taraf hidup masyarakat mendatangkan keuntungan dan pelestarian obyek itu sendiri. Dan semua itu, dapat di dasarkan pada tujuan dan manfaat penulisan tugas akhir ini.

Pengembangan Pariwisata adalah segala kegiatan dan usaha yang terkoordinir untuk menarik wisatawan, menyediakan semua prasarana dan sarana, barang dan jasa fasilitas yang diperlukan guna melayani kebutuhan wisatawan.

Menurut Oka A. Yoeti (2005: 20) yang berisi tentang, Hal- hal yang perlu diperhatikan dalam pengembangan suatu obyek wisata: Obyek wisata itu harus mempunyai apa yang disebut sebagai Something to see, artinya di tempat tersebut harus mempunyai daya tarik khusus yang dapat dilihat terutama yang berbeda dengan yang dimiliki tempat lain. Dilokasi obyek wisata itu harus tersedia dengan apa yang disebut Something to do, Artinya di lokasi tersebut harus pula ada kegiatan yang dilakukan, contohnya fishing, tracking, dan lain-lain. Dilokasi obyek wisata tersebut harus tersedia apa yang disebut dengan Something to buy yang artinya dilokasi tersebut harus terdapat fasilitas untuk berbelanja (Shopping) terutama souvenir sebagai oleh-oleh untuk dibawa pulang.

Dalam pengembangan suatu obyek wisata perlu diperhatikan tentang sarana dan prasarana, yang dimaksud sarana adalah semua bentuk perusahaan yang dapat memberikan pelayanan kepada wisatawan. Sedangkan yang dimaksud 
dengan prasarana (infrastructures) adalah semua fasilitas yang dapat memungkinkan proses perekonomian berjalan dengan lancar sedemikian rupa, sehingga dapat memudahkan manusia untuk dapat memenuhi kebutuhannya menurut Oka A Yoeti (2005; 93). Dalam pengertian ini yang termasuk dalam sarana adalah : Akomodasi, Restoran, Toko souvenir

Yang dimaksudkan prasarana adalah: "Semua fasilitas yang memungkinkan proses perekonomian dapat berjalan dengan lancar sedemikian rupa, sehingga dapat memudahkan manusia untuk memenuhi kebutuhannya yang berfungsi untuk melengkapi sarana kepariwisataan sehingga dapat memudahkan manusia untuk memenuhi kebutuhannya." Dalam pengertian ini yang termasuk dalam prasarana adalah : Sistem penyediaan air bersih, Pembangkit tenaga listrik, Jaringan jalan raya dan Telekomunikasi.

Sebagai tolak ukur dan untuk mengetahui prioritas pengembangan daerah wahana wisata pantai dapat digunakan kriteria yang mendasari penilaiannya menurut Ditjen PHPA (1993):

1. Daya Tarik. Unsur-unsur daya tarik wana wisata pantai meliputi : (a) lebar pantai diukur pada waktu air laut surut dengan panjang pantai minimal $1 \mathrm{~km}$; (b) Keselamatan tepi laut pantai ; (c) Kebersihan laut ; (d) Keindahan; (e) Jenis pasir ; (f) Kebersihan dan (g) variasi kegiatan.

2. Potensi pasar. Unsur kriteria potensi pasar meliputi: (a) jumlah penduduk kabupaten pada radius $75 \mathrm{~km}$; (b) jarak obyek dari terminal bus atau non-bus dan pintu gerbang udara regional dan Internasional.

3. Kadar hubungan. Kriteria penilaiannya meliputi: (a) kondisi jalan, (b) jumlah kendaraan bermotor ; (c) Frekuensi kendaraan umum, (d) jumlah tempat duduk transportasi utama menuju lokasi per minggu.

4. Kondisi lingkungan. Kriteria kondisi lingkungan meliputi (a) tata guna lahan atau perencanaan, (b) status pemilikan lahan, (c) Kepadatan penduduk ;(d) sikap masyarakat, (e) Mata pencaharian : (g) Pendidikan ; (h) Media yang masuk ; (i) Dampak sumber daya alam biologis, dan (j) Sumber daya fisik.

5. Pengelolaan perawatan dan pelayanan. Kriteria penilaian tersebut meliputi unsur-unsur: (a) pemantapan orga-nisasi atau pengelola ; (b) Mutu pelayanan, dan (c) Sarana perawatan dan pelayanan.

6. Kondisi iklim. Unsur-unsur tersebut meliputi: (a) Pengaruh iklim terhadap waktu kunjungan, (b) suhu udara pada musim kemarau, (c) jumlah bulan kering per tahun ; (d) rata-rata penyinaran matahari pada musim hujan ; (e) kecepatan musim angin ; dan (f) Kelembaban udara.

7. Akomodasi. Unsur-unsur yang digunakan dalam kriteria ini didasarkan pada jumlah kamar yang berada pada radius $75 \mathrm{~km}$ dari obyek wisata

8. Prasarana dan sarana penunjang. Unsur-unsur tersebut meliputi : (a) Prasarana yang ada pada radius 2 $\mathrm{km}$ dari batas kawasan: (b)sarana penunjang; (c) Fasilitas Khusus; dan (d) Fasilitas kegiatan.

9. Tersedianya air bersih merupakan faktor yang perlu dalam pengembangan suatu obyek, baik untuk pengelolaan maupun pelayanan. Macam-macam unsur yang digunakan dalam menilai kriteria ini adalah ; (a) Jarak sumber air terhadap lokasi obyek wisata; (b) Debit sumber air; (c) dapat tidaknya dialirkan.

10. Hubungan dengan wisata lain. Unsur-unsur yang dinilai dalam kriteria ini didasarkan ada dan tidaknya serta jumlah obyek wisata lain dengan nilai daya tarik minimal 100, dalam radius $75 \mathrm{Km}$ dari obyek wisata yang dinilai. 


\section{METODE}

Jenis penelitian menggunakan teknik deskriptif dengan sampel adalah pengunjung sebanyak 50 orang yang diambil secara aksidental, pengumpulan data menggunakan kuesioner dan analisa data secara deskriptif.

\section{HASIL}

Berdasarkan data hasil penelitian tentang kondisi nyata Objek Wisata Bandar Kayangan sebagai berikut: pengembangan Objek Wisata Danau Bandar Kayangan tergolong ke dalam hal Sangat Baik (SB) yang dinyatakan oleh 4 orang yaitu $66.7 \%$. Hal ini dikarenakan beberapa alasan yaitu: Bahwa di Kota Pekanbaru sangat minim tempat wisata sehingga sangat diperlukan adanya objek wisata agar masyarakat tidak pergi keluar Kota Pekanbaru untuk pergi berlibur. Adanya Objek Wisata Danau Bandar Kayangan ini akan menambah Pendapatan Asli Daerah (PAD) Kota Pekanbaru dan juga akan menambah income masyarakat tempatan. Adanya Objek Wisata Danau Bandar Kayangan ini dapat membuat wisatawan yang datang ke Kota Pekanbaru akan meningkat dan Kota Pekanbaru akan lebih dikenal lagi. Dinas Pariwisata dalam melalukan pemasaran untuk meningkatkan kunjungan ke Objek Wisata Danau Bandar Kayangan tergolong ke dalam hal Cukup Sulit (CS) yang dinyatakan oleh 4 orang yaitu $66.6 \%$. hal ini dikarenakan beberapa alasan yaitu: Dana yang disediakan untuk melakukan promosi tidak terlalu besar sehingga Dinas Pariwisata melakukan promosi apa adanya. Belum selesainya pembangunan pengembangan Kawasan Danau Kayangan sehingga persiapan untuk melakukan promosi belum dilakukan secara baik oleh Dinas Pariwisata.

Pemerintah Kota Pekanbaru sudah melakukan upaya pengembangan wisata di Danau Bandar Khayangan Lembah Sari, upaya yang dilakukan tahun 2012 ini yaitu menjamin transportasi umum terutama angkutan umum untuk bisa masuk ke lokasi wisata idaman masyarakat Pekanbaru tersrebut. Pembangunan kawasan wisata Danau Bandar Kayangan sendiri sudah mulai dimatangkan tahun ini. Pemko menganggarkan total Rp. 4,5 miliar. Yakni untuk pembangunan kolam renang tanpa water boom senilai Rp. 3 miliar dan memasukkan jaringan listrik Rp. 1,5 miliar. Sedang Pemerintah Provinsi Riau sudah menganggarkan dana Rp. 8 miliar. Peruntukkannya, pembangunan akses jalan masuk senilai Rp. 3 miliar melalui Dinas PU Provinsi dan Rp. 5 miliar untuk pembangunan play kid dan amphi theater melalui Dinas Pariwisata Provinsi Riau. (Http://www.riaudailyfhoto.com/read/2001 1/04/04/68157/55/9/festival-danau-buatan2011-html)

Berikut ini penulis uraikan hambatanhambatan Dinas pariwisata dalam mengembangkan Kawasan Objek Wisata Danau kayangan, yaitu:

1. Pengelolaan yang belum Memadai

Perusahaan Daerah (PD) Pembangunan yang saat ini menjadi pengelola Danau Bandar Kayangan, belum cukup mampu mengelola kawasan wisata Danau Bandar Kayangan dengan baik sehingga diperlukan pengelolaan yang lebih profesional. Upaya Pemerintah Kota Pekanbaru mengembangkan kawasan wisata DB hingga kini belum kunjung direalisasi. Berbagai macam cara yang dilakukan, mulai dari dikelola sendiri sampai mencari pihak ketiga yang hingga saat ini keinginan mengembangkan DB masih belum menunjukkan ada perkembangan yang signifikan. Tidak itu saja, walaupun ada sejumlah investor datang ke Pemko mengaku berminat mengembangkan kawasan itu, nyatannya, Danau Bandar Kayangan tak juga ditata lebih menarik.

Untuk merealisasikan target agar Danau Bandar Kayangan menjadi objek wisata yang diinginkan, Dinas Kebudayaan dan Pariwisata (Disbudpar) Riau, berusaha menggandeng perusahaan pengelola Jatim Park untuk ikut mengelola Danau Bandar Kayangan . Pengelola Jatim Park, merupakan perusahaan yang dibentuk oleh swasta dan Pemerintah Daerah Lamongan. 
Persentasenya, 40 persen saham pemda Lamongan sedang swasta 60 persen. Dari besaran saham tersebut, pemasukan PAD mencapai Rp. 9 miliar setiap tahunnya. Sayangnya, pengelola Jatim Park agak pesimis dengan prospek Danau Bandar Kayangan . Mengingat jumlah penduduk Pekanbaru yang hanya 800 ribu dan penduduk Riau yang hanya 4 juta jiwa. Namun Pemko tak berputus asa. Data Kota Pekanbaru secara keseluruhan, dikirimkan ke pengelola Jatim Park untuk dijadikan bahan pertimbangan.

\section{Belum adanya investor}

Dinas Kebudayaan dan Pariwisata (Disbudpar) Pekanbaru mengharapkan keikutsertaan para investor dalam rencana pengembangan obyek wisata unggulan Danau Bandar Kayangan Kota Pekanbaru. Untuk pengembangan obyek wisata unggulan Danau Bandar Kayangan masih terkendala dana, karena investor yang berkunjung ke lokasi selalu mengajukan berbagai permintaan dan belum bisa dipenuhi. Permintaan investor tersebut antara lain penduduk Kota Pekanbaru harus mencapai minimal satu juta jiwa seperti yang pernah di tinjau oleh investor pengelola Ancol dari Jakarta. Pihak Ancol mengharapkan dari hitung-hitungan mereka jumlah penduduk Pekanbaru harus mencapai minimal satu juta, sementara saat ini jumlah penduduk belum mencapai 800 ribu.

Saat ini sejumlah investor sudah ada yang mulai melirik Objek Wisata Unggulan Danau Bandar Kayangan ini, diantaranya ada pihak dari pengelola Ancol dari Jakarta, kemudian juga investor dari Malaysia, tetapi belum ada kepastian hingga saat ini. Berdasarkan rencana induk yang dibuat untuk pembangunan Objek Wisata Unggulan Danau Bandar Kayangan ini diperhitungan menghabiskan dana sebesar Rp. 250 Miliar. Hingga saat ini Kota Pekanbaru sedang mencari dan mengusahakan mendatangkan para investor tersebut. Sedangkan dana yang dimiliki oleh Disbudpar dari APBD untuk 2009 hanya Rp. 3,8 Miliar, dan untuk tahun depan juga akan dianggarkan kembali dengan nilai yang sama.
3. Kurangnya pengawasan terhadap kontraktor

Pantauan di lapangan, banyak bangunan-bangunan yang baru selesai dikerjakan dan diserahterimakan oleh kontraktor ke pihak Disbudpar Riau, kini kondisinya sudah hancur. Misalnya, dalam pembangunan jalan beton. menemukan, bahwa jalan beton yang baru dibangun kondisinya sudah ada yang retak-retak. Dan kejadian tersebut ditemukan di sekitar STA 300 sebelum Box Culvert I dan di jalan beton menuju rumah panggung. Pihak kontraktor pelaksana sepertinya sengaja menutupi jalan beton yang hancur tersebut dengan aspal. Tujuannya agar tidak kelihatan dengan jelas. Padahal, jangan dari jarak 5 meter, dari jarak 10 meter saja, jalan beton yang hancur tersebut sangat jelas kelihatan.

Sangat disayangkan memang, jalan beton yang notabene, sangat jarang untuk dilalui kenderaan berat, justru kondisinya sudah hancur. Hal ini membuktikan bahwa kualitas dari jalan beton yang dibangun tersebut memang tidak bagus alias kualitas murahan. Selain itu, pembangunan jalan tangga dan penimbunan tanah di sekitar turap dan jalan tangga juga sudah hancurhancuran. Buktinya, banyak jalan tangga, yang sudah retak-retak dan Paving Blok yang dipasang surut atau anjlok. Hal ini terlihat jelas di sekitar Detail Jalan Tangga I atau sekitar STA 404 menuju pekerjaan rumah panggung tepatnya sekitar 15 meter dari bangunan toilet. Sangat jelas terlihat, lebar patahan jalan tangga hampir mencapai $1 \mathrm{~cm}$ membelah tangga dari atas ke bawah.

Dan yang lebih parah adalah pada pekerjaan Detail Jalan Tangga 4, tepatnya Tangga A, Tangga $B$ dan Tangga $C$. Tangga-tangga yang telah ditutupi dengan Paving Blok tersebut, disamping mengalami surut/turun dan hampir berpisah dari dinding turap penahan dataran rumah panggung, juga mengalami keretakan dan patahan yang hampir mencapai $4 \mathrm{~cm}$. Hal yang sama juga terjadi di dataran sekitar Rumah Panggung yang telah ditutupi dengan Paving Blok, juga mengalami 
penurunan. Bahkan ada yang sudah turun mencapai $25 \mathrm{~cm}$ dari ujung turap penahan tebing. Sedangkan dalam pekerjaan pembangunan sarana di arena Amphiteater, paving blok yang dipasang sepertinya asal jadi, dan tidak melaksanakan item pekerjaan di sekitar Arena Amphiteater. Misalnya, pemberian tanah hitam dalam pot yang sudah dibangun. Dan cat yang digunakan untuk mengecat besi tribun penonton, sepertinya kulitas murahan, dengan bukti banyak tempat duduk dari besi hollow yang sudah berkaratkarat.

Http://www.riaudailyfhoto.com/read/20011/0 4/04/68157/55/9/festival-danau-buatan-2011html)

Berikut ini penulis sajikan beberapa tanggapan wisatawan terhadap keberadaan Objek Wisata Danau Bandar Kayangan yang ada Di Kota Pekanbaru.

1. Terhadap daya tarik Objek wisata Danau Bandar Kayangan

Daya tarik yang disajikan oleh suatu objek wisata merupakan hal yang harus dimiliki karena dengan hal tersebut akan membuat wisatawan atau wisatawan akan tertarik untuk mendatanginya serta memakai fasilitas yang ditawarkan. Danau Bandar Kayangan merupakan objek wisata yang cukup dikenal dan memiliki daya tarik danau yang dikelilingi oleh hutan yang rimbun yang dinilai Baik (B) oleh 24 orang yaitu $48 \%$.

2. Terhadap keamanan dan Kenyamanan Di Danau Bandar Kayangan

Keamanan dan kenyamanan merupakan hal yang paling utama dan harus dimiliki oleh suatu objek wisata sehingga wisatawan merasa terlindungi dan betah untuk menikmati objek wisata tersebut. Kawasan Danau Bandar Kayangan dirasakan oleh wisatawan cukup aman karena tidak pernah terjadi peristiwa kecopetan, kemalingan, pemerasan atau hal-hal yang merugikan terhadap wisatawan. Dengan demikian keamanan dan kenyamanan wisatawan dapat tercipta dengan baik yang dinilai rata-rata Baik (B) oleh 31 orang yaitu $62 \%$.
3. Terhadap Fasilitas yang tersedia di Kawasan Danau Bandar Kayangan

Fasilitas yang baik dan memadai merupakan hal pendukung yang harus dimiliki oleh sebuah objek wisata. Fasilitas yang berupa akses yang baik menuju kesana dan fasilitas yang disediakan untuk makan dan minum serta fasilitas lainnya akan membuat objek wisata tersebut menjadi tempat yang cukupdisenangi oleh wisatawan untuk dikunjungi. Dinas Pariwisata dalam melakukan pengelolaan Objek Wisata Danau Bandar Kayangan sudah berusaha untuk melengkapi fasilitas tersebut namun masih belum optimal ratarata menjawab Cukup Baik (CB) yaitu 29 orang dengan persentase $58 \%$.

\section{Terhadap Keindahan Objek Wisata Danau Bandar Kayangan \\ Objek Wisata Danau Bandar} Kayangan memiliki keindahan alam yang cukup mempesona sehingga banyak diminati oleh wisatawan. Keindahan alam dengan panorama yang di tampilkannya membuat wisatawan merasa nyaman dan senang mengunjungi Objek Wisata Danau Bandar Kayangan . Tempat yang menarik dengan udara yang sejuk serta pemandangan yang indah membuat para wisatawan merasa segar dan nyaman selama berada disana. Apalagi keindahan alam ini dipadukan dengan penataan yang baik akan membuat Objek Wisata Danau Bandar Kayangan lebih dikagumi lagi oleh wisatawan yang mana rata-rata wisatawan menjawab Cukup Indah (CI) yaitu 36 orang dengan persentase $71 \%$.

\section{PEMBAHASAN}

Strategi Pengembangan Objek Wisata Danau Bandar Kayangan Untuk meningkatkan kunjungan wisatawan Oleh Dinas Pariwisata Di Pekanbaru. Minimnya tempat wisata alam dan bermain di Kota Pekanbaru membuat beberapa tempat bermain yang berada di mal-mal dan juga hotel-hotel yang menyediakan water park 
menjadi incaran warga Pekanbaru dan juga dari kabupaten/kota di Riau. Namun tahun 2012 dan dua tahun ke depan Danau Bandar Khayangan Lembah Sari bakal menjadi tempat incaran masyarakat untuk menghabiskan waktu liburan. Dengan luas lahan mencapai 14 hektar dan luas danau mencapai 8 hektar, wisata Danau Bandar Kayangan terletak di Lembah Sari, Pekanbaru (lebih 10 kilometer dari kota Pekanbaru) bisa dijadikan sebagai objek wisata se-Sumatera. Danau Bandar Kayangan semula berbentuk bendungan irigasi yang kini dipoles menjadi salah satu tempat wisata masyarakat Pekanbaru, Riau memang masih bernuansa alami. Danau ini dari tahun ketahun masih memiliki panorama indah, sejuk, nyaman dan berbukit. Tumbuhan pepohonan beraneka ragam ada disisi jalan, memungkinkan dikembangkan sebagai tempat atraksi wisata tirta seperti berenang, memancing, bersepeda air dan lain-lain.

Kawasan ini berada di sebuah tanjung pada sebuah danau yang dibuat dengan membendung aliran air. Konsep Masterplannya adalah A Holiday Park / Area For Everyane (Taman Hiburan / Kawasan untuk semua orang).

Kawasan ini terbagi atas 11 zona yaitu: Zona Taman Air. Zona Jet Coaster dll. Zona Rumah Kaca. Zona Taman Bermain. Zona Bungalow. Zona Gokart. Zona Restoran dan Roda Putar. Zona Pemancingan. Zona Petualangan / Outbond. Zona Piknik dan Zona Pusat Jajan.

Dalam melakukan pengembangan Kawasan Objek Wisata Danau Bandar Kayangan Pemerintah Kota Pekanbaru tidak main-main. Pemerintah Kota merencakan tahapan pembangunan dengan membuat masterplan arahan pengembangan kawasan wisata Danau Bandar Kayangan sebagai berikut ini:

\section{Arena Bermain}

Arena bermain direncanakan menjadi satu-satunya dan terbesar yang ada di pulau Sumatra. 10 (sepuluh) permainan yaitu :Astro Swinger kapasitas 28 orang. Jet Coaster sepanjang 800 meter kapasitas 30 orang.
Space Gyro kapasitas 36 orang. Shocking Car sebanyak 20 unit kapasitas 40 orang. Jet Star kapasitas 32 orang. Marry Go Round kapsitas 34 orang. Cannon .Machine Gun sebanyak 10 unit dengan 10 target. Shooting Gallery sebanyak 10 unit dengan 50 target. A Mirror House dengan koridor sepanjang 40 meter dan lebar 1,2 meter. $A$ Mysteri House dengan luas 12 x 15 m2. Sebuah jalur/track untuk permainan Go Kart juga akan dibangun dengan panjang $1,2 \mathrm{~km}$, lebar 8 meter, dengan 20 unit go kart yang disediakan akan melengkapi seluruh area bermain ini.

\section{Taman Air}

Sebuah taman air yang luas akan dibangun yang dapat dikunjungi oleh orang dewasa maupun anak-anak. Taman ini akan diisi dengan fasilitas yang sangat bagus berupa seluncuran, air mengalir, pantai berombak, air curah, dan sebagainya.

\section{Taman Bermain Anak-Anak Dan Taman Rekreasi \\ Taman anak-anak akan dibangun} dengan menggunakan rumput dan atap yang tembus cahaya. Menyediakan berbagai alat permainan yang dibuat secara halus dari bahan berkualitas untuk menjaga keselamatan anak-anak. Taman rekreasi akan ditempatkan di pinggir danau dengan rumput hijau yang segar dimana wisatawan dapat bermain di pinggir danau tersebut. Ketika para orang tua menunggu anaknya bermain, mereka dapat menghabiskan waktu dengan melihat-lihat taman bunga dengan suatu area khusus untuk tanaman anggrek.

\section{Venue Ski Air}

Untuk keperluan pertandingan cabang ski air Pekan Olahraga Nasional (PON) XVIII tahun 2012, Pemerintah Kota (Pemko) Pekanbaru membangun venues Ski Air di Danau Bandar Kayangan, Rumbai. Untuk membangun venues Ski Air itu Pemko Pekanbaru telah menganggarkan dana sebesar Rp. 2,5 miliar. Danau Bandar Kayangan dipilih sebagai tempat 
pelaksanaan cabang ski air, karena dinilai cukup presentatif. Danau yang berada di kecamatan Rumbai itu tinggal pembenahan saja sehingga nantinya bisa menjadi tempat lomba air air. Sebagai salah satu ibu kota tuan rumah dalam pelaksanaan PON 2012, pihaknya tetap turut serta dalam membangun venues-venues cabang olahraga yang diperlombakan, termasuk di antaranya untuk perlombaan ski air yang dilaksanakan di Danau Bandar Kayangan. Untuk pembangunan venues ski air tersebut, menggunakan anggaran dari APBD tahun anggaran 2011.

\section{Plaza Seni Dan Dermaga Pancing}

Area ini akan terdiri dari teater terbuka dengan kapasitas 200 orang, restoran mengapung, 1 hektar taman air dengan sepeda air dan sampan kecil. Tempat pemancingan disediakan dengan menggunakan dermaga kayu yang luas. Setiap minggunya akan menampilkan musik langsung dengan penyanyi-penyanyi bersuara merdu. Untuk saat ini Pemerintah Kota masih melakukan pembenahan besar-besaran, tidak menutup kemungkinan kawasan ini nantinya akan dikembangkan menjadi kawasan wisata seperti universal studio di Singapura atau paling tidak seperti Dunia Fantasi di Jakarta. Banyak sekali perubahan dan pembenahan yang dilakukan Pemko untuk meningkatkan kualitas pariwisata seperti perbaikan fasilitas, akses transportasi dan komunikasi. Wisata Danau Khayangan Lembah Sari merupakan salah satu tempat wisata Pekanbaru yang bernuansa alami. Tujuan wisata yang satu ini berlokasi di Kecamatan Rumbai.

\section{SIMPULAN}

Animo masyarakt terhadap pengembangan objek wisata danau Banda Kayangan cukup baik. Kemudian strategi Dinas Pariwisata dalam mengembangkan Objek Wisata Danau Bandar Kayangan agar menjadi objek wisata yang dapat dihandalkan di Kota Pekanbaru melakukan beberapa hal yaitu: 1) Membagi wilayah Danau Bandar
Kayangan menjadi beberapa zona; 2) Membuat masterplan arahan pengembangan. Ada beberapa hambatan yang dimiliki oleh Dinas Pariwisata dalam melakukan pengembangan Objek Wisata Danau Bandar Kayangan. Hal itu tentu saja sangat menghambat terhadap pengembangan yang sudah direncanakan. Hambatan yang ada tersebut yaitu: Pengelolaan yang belum memadai, Tidak adanya investor yang berminat menanamkan modalnya, Adanya beberapa pejabat yang melakukan korupsi terhadap dana pengembangan dan kurangnya pengawasan terhadap kontraktor.

\section{DAFTAR RUJUKAN}

Arnoldo C. Hax dan Nicholas S. Manjluk. 1991. The Strategy Process and Concept: a pragmatic approach, Prentice Hall International Ed, Gramedia Pustaka Utama. Jakarta.

Badan Pusat Statistik. 2011, Pekanbaru

Bryden, M John. 2003. Pariwisata Dalam Ekonomi. Kanisius. Yogyakarta

Dinas Pariwisata Seni Dan Budaya Propinsi. 2011. Brosur-brosur.

Ditjen PHPA.1993. Strategi Pengembangan Produk Dan Promosi Ekowisata, Jakarta

Fandeli. 2005. Pengembangan Daya Tarik Wisata. Pustaka Sinar Harapan. Jakarta.

Fred R. David. 2005. Strategic Management: Concepts and Cases, Gramedia Pustaka Utama, Jakarta.

Garis-garis Besar Haluan Negara Republik Indonesia (GBHN). 1993

Gerry Johnson dan Kevan Scholes. 2010. Exploring Corporate Strategy, Gramedia Pustaka Utama , Jakarta. 
Http://www.riaudailyfhoto.com/read/20011/0 4/04/68157/55/9/festival-danau-buatan2011-html

Happy Marpaung. 2002. Gejala Pariwisata. Alfabetha. Bandung.

Igor Ansoff . 1990. Implanting Strategic Management, Prentice Hall, Gramedia Pustaka Utama, Jakarta.

I Gede Ardika, 1997, Penyelenggaraan Operasi Perjalanan Wisata, Grasindo, Jakarta.

Instruksi Presiden. 1996. No. 9. Republik Indonesia

John A. Pearce II dan Richard B. Robinson Jr. 2003. Strategic Management, formulation, implementation and control, Irwin McGraw-Hill, Gramedia Pustaka Utama, Jakarta.

Kaelany H D. 2002, Pengetahuan Kepariwisatan, Alfabetha, Bandung.

Ketetapan MPR No.II/MPR/1983

Ma. Desky, 2000, Manajemen Perjalanan Wisata, Adicita, Yogyakarta

Oka A. Yoeti. 1996. Ilmu Pariwisata Sebuah Pengantar Sederhana. Jakarta. PT. Pradnya Paramita.

Oka A. Yoeti 2001. Pengantar Ilmu Pariwisata. Bandung, Angkasa
Oka. A. Yoeti. 2005, Pemasaran Pariwisata Terpadu, Angkasa, Bandung.

Sumadi Suryabrata.1992 Metodologi Penelitian, Rajawali Pers, Jakarta.

Sihite. 2000, Perjalanan Wisata. Pustaka Sinar Harapan, Jakarta

Spillanne, James J. 2004. Ekonomi Pariwisata. Sejarah dan prospeknya

Soekadijo, R.S. 2006. Anatomi Pariwisata. Jakarta. Gramedia.

Tourism, Art and Culture Office, 2011, Obyek dan Daya Tarik Wisata, Dinas Pariwisata Seni Dan Budaya, Pekanbaru.

Tontje Tnunay, 2008, Kegiatan Produk Pariwisata, Pradnya Paramita, Jakarta

Witt \& Moutinho. 1998, Pemasaran Pariwisata, Pradnya Paramita, Jakarta

WF Glueck dan LR Jauch. 2009, Manajemen strategis dan kebijakan perusahaan, Pustaka Sinar Harapan, Jakarta. 